\title{
THE IMPACT OF TRAUMATISM ON THE PROFESSIONAL AGING: THE CASE OF ELITE SPORTS
}

\author{
Anna V. Ermilova1', Ilvis Abelkalns ${ }^{2}$ \\ ${ }^{1}$ Lobachevsky State University of Nizhni Novgorod, Russia \\ ${ }^{2}$ University of Latvia, Latvia
}

\begin{abstract}
The article outlines the problem of traumatism, which is analyzed from the viewpoint of the socio-medical aspect. The peculiarities of the impact of traumatism on the professional sports career were revealed through the analysis of the elite athletes' biographies ( $n=296$ respondents). The research was carried out applying the qualitative research design (biographical research). The assessment of life narratives of high-performance athletes performing on the world arena was carried out applying the criterion of traumatism and its impact on the athletes' lives ( the athletes' biographies are accessible through opensource Internet resources). The data obtained in the research framework revealed the possible trajectories of the impact of traumatism on the course of the professional sporting career: the process of career stagnation, professional success, the process of completion/ termination of a sporting career. The career stagnation was observed among all the respondents, which is predetermined by the rehabilitation process they had to go through. Based on the data obtained in the research framework, the conclusion can be drawn that reintegration into elite sports is primarily based on the resource potential of the athlete: the resources of the family/ the loved ones, the athlete's own capacity, as well as the state support provision. The possible trajectories of professional aging were identified, namely, high resource capacity, the reduction/loss of resource capacity (disability), zeroing of resource capacity (lethal outcome). In addition, the data showed that the potential trajectory for the reintegration was usually identified within the two directions: firstly, sports and physical culture; secondly, other professional spheres. It should also be highlighted that professional aging puts forward the issues related to social security of high-performance athletes worldwide. Therefore, the issue of reviewing the reintegration criteria into the education system or professional and labour market upon the completion of the sporting career is of highest topicality provided that it would positively impact both the positive capacity of the population group and the prestige of high-performance sports worldwide. The research results allow drawing the conclusion that the accumulated resources in the course of building and implementing a professional sports career have a positive impact on the duration of the professional age of a representative of elite sports, in its turn, providing the possibility to easily adjust to the new life upon the completion of the sports career.
\end{abstract}

Keywords: Dual career, high-performance sports, professional aging, student-athlete, traumatism 


\section{Introduction}

Traumatism in professional sports is the most common phenomenon having mental consequences that ambiguously affect the personality of an athlete and the sporting career. Within the scientific literature, two approaches to the consideration of traumatism as a socio-medical phenomenon prevail.

One of them is associated with the interpretation of trauma as a factor that has a positive impact on the advancement of sports achievements. According to a researcher in the field of physical culture and sports (FCS) (Bakunyaeva, 2018a), traumatism has a significant impact on the professional success of athletes $(p<0.001)$. Athletes with injuries have a higher level of professional success (Bakunyaeva, 2018b).

Based on the second approach, traumatism can lead not only to the loss of the possibility of personal realization in high-performance sports - early termination of a sports career, but also to the loss of a person's life-forming function - self-service (disability), and sometimes even the lethal outcome. Increasingly, the death of athletes occurs during the sports training process, with their sudden retirement from sports.

Sports injuries account for $1.3-7.2 \%$ of the total number of injuries. Males are injured about 3 times more often than females. Most often, arms and legs are affected, less often the head and the small of the back. The location of sports injuries depends on the type of sport, for instance, most leg injuries occur in football, while hand injuries - in gymnastics. The main causes of sports injuries are as follows: shortcomings in the organization and methodology of training, inappropriate place for training, low-quality equipment, violation of discipline and rules, ignorance of medical supervision (Sports Injury, 2012).

The impact of traumatism on a sporting career was considered by the research group of N. Yu. Fedunina, A. I. Grushko, A. V. Kovaleva, G. S. Bannikov, as well as D. V. Fedulova and G. A. Yamaletdinva. A significant contribution to the study of the issue of the resource capacity of the representatives of the Physical Culture and Sports was made by G. B. Gorskaya and Z. R. Sovmiz, M. I. Zolotov (Gorskaya \& Sovmiz, 2018; Fedulova \& Yamaletdiva, 2017; Fedunina et al., 2018; Zolotov, 2003. Fedotova (2010) and Butova \& Demyanova (2018) have contributed to the study of the problems of social adaptation of athletes who have completed their sports careers (Fedotova (2010); Butova \& Demyanova (2018). 


\section{Method}

Professional athletes' narratives on past injuries clearly reveal the ambiguous impact of injuries on the further life of athletes. Based on this view, the research goal was to explore the peculiarities of the impact of injuries on the professional career of athletes (professional ageing) with the aim to identify possible trajectories of professional sports career termination (professional aging).

The research aim was achieved through the analysis of elite athletes' biographies $(n=296)$ implemented applying a qualitative research approach (biographical method). The assessment of the elite athletes' life stories available in the open-source Internet resources was conducted based on the criterion of traumatism and its impact on the athlete's fate. The study included $48 \%$ of males and $52 \%$ of females representing sports, such as rhythmic and artistic gymnastics, soccer, hockey, basketball, cycling, motorsports, wrestling, mountain climbing, and boxing.

\section{Results and Discussion}

The duration of the professional career of athletes is a multifactorial social phenomenon. The factors that determine it may be as follows: a kind of sport; length of stay in the sports field; drugs/doping use; athlete's physiology; the presence and severity of injuries; the level of stress resistance; the level of social services provided by health and social protection systems; state social policy in the development of physical culture and sports.

According to Dr. McNamara, a specialist in the field of health preservation of professional athletes, premature aging is specifically characteristic of elite athletes (McNamara, 2012). This fact can negatively affect the duration of the professional age, i. e., the age (number of years) determined by the characteristics of professional activity (in our case, sports practices/ activities). Premature professional aging is an accelerated, pathological phenomenon that proceeds in a different way if compared to the natural physiological aging. Currently, the diagnostics for determining premature aging has been developed, which should be applied to this category of the population to expand the possibilities of painless integration of athletes into the society upon the termination of their sports career. Based on the opinion of the Belarusian Medical Academy M. S. Pristrom, S. L. Pristrom, S. S. Simonkova (Pristrom, Pristrom \& Simakov, 2015), the criteria for determining premature aging may be as follows:

1. Subjective manifestations (fatigue, general weakness, loss of vitality, sleep disturbance, emotional lability); 
2. Objective signs (loss of teeth and hair, decreased visual acuity, changes in the spine, the appearance of wrinkles, etc.). McNamara suggests that athletes at the age of 24-25 look much older, they have wrinkles, hair falls out. Even if the athlete does not acknowledge taking steroids, over the time, it turns out that they were consuming them (McNamara, 2012);

3. The biological age of the organism. This is a special indicator that makes it possible to assess the changes in the organs and systems of an aging organism, and the state of its health.

Diseases and injuries received during the sports training process can accelerate the process of premature professional aging. This substantiates the necessity to identify the trajectories of the impact of injuries in the field of elite sports on the course of a professional career. The peculiarities of the impact of traumatism on the professional sports career were revealed through the analysis of the elite athletes' biographies (see Fig. 1).

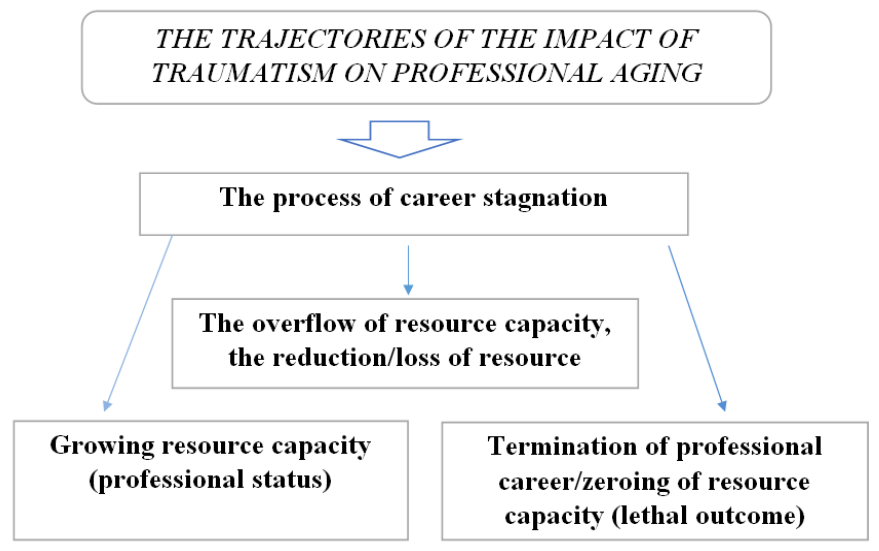

Figure 1. Trajectories of the Impact of Traumatism on Athletes' Professional Career (authors of the study)

The biographical analysis revealed that injuries have a multidirectional vector of impact on professional sports career. It should be highlighted that all traumatized athletes, without any exception, go through the stage of career stagnation ( $n=296)$, which is due to the rehabilitation process, which proceeds differently in the space-time aspect, depending on the severity of the injury. However, it cannot be stated unequivocally that the more complex the trauma of an athlete, the less chance of reintegration into the sphere of elite sports. This is due to the athlete's resource potential: the resources of the family/loved ones, the volume and specifics of their own resources, as well as the resources of the state (for example, the 
costs of the health care system). The state, as the agent participating in the rehabilitation of athletes, plays a vital role. For instance, medical expenses in the United States for visiting emergency departments for sports injuries exceed \$ 935 million annually (Youth Sports, 2024).

Upon the completion of the rehabilitation measures, the athlete, returning to the sport, reaches new sports heights (high level of resourcefulness) the level of professional success or the ability to deliver good results is minimized (low level of resourcefulness) - a decline in professional success. This way, 17 athletes who received the most serious injuries (e. g., a spinal fracture - Battiston, brain damage - Totmianina, displacement of vertebral discs - Lemieux) were able not only to restore their health, return to sports, but also progress to a new stage. However, the analysis of the biographies also reveals the reverse side of the "medal" when the athlete who returned to the arena not only failed to continue a professional career, but even to return to the professional shape that they had before the injury ( $n=23$ ), which obviously leads to the degradation of sports career as such. This is the case, for instance, for the high-performance athletes E. da Silva, Y. Kudryavtseva, L. Utyasheva. It should also be specified that sometimes athletes who received a serious injury may start practising paralympic sports.

The next trajectory of the influence of injuries on a sports career is its completion as a result of disability or its termination (death of an athlete) in the course of sports and training activities. Injuries such as head bruises and a fracture of the spine $(n=19)$, first of all, lead to an athlete acquiring the status of a "person with disabilities" which subsequently most frequently leads to paralysis of the athlete's body. The following outstanding athletes can be viewed as examples of such a trajectory for completing a sports career: M. Abdusalamov (head injury), E. Mukhina (fracture of the cervical spine), S. Pogiba (head injury), A. Marinescu (spinal injury), I. Skvortsov (fracture of the spine), A. Zanardi (amputation of the legs), R. Zismer (head injury). The motor activity of these athletes is difficult or even impossible. Almost none of them was able to return to the sphere of physical culture and sports, even in the status of a "coach". It should not be forgotten that it is coaching, consultancy work in this field of activity for many of them, sometimes in wheelchairs, can be the very bridge that would connect their sports past with the present, preventing depression and loneliness.

This social fact may indicate, firstly, the lack of the necessary level of resources for the restoration of both the former athletes themselves, their entourage, and the state as the main agent that implements social policy; secondly, the absence of a practical possibility of resource overflow after an injury. As a consequence, the impossibility of self-realization in the field 
of coaching can be directly related to health issues, and to the lack of an effective system of state support for athletes with disabilities in labour market integration.

Sociological research "Medical and Social Adaptation of Highly Qualified Athletes in the Post-Sports Period" conducted under the leadership of Fedotova (2010) $(n=160)$ also confirms the negative impact of high-performance sports on human health, as a result of which the status of "disabled" can be acquired not only during the development of a sports career, but also upon its completion. The data show that $86 \%$ of former highly qualified athletes-gamers reveal chronic pathology of various organs and systems in the early post-sports period, chronic pathology of various organs and systems. In the structure of chronic pathology, the leading place in the post-sports period belongs to diseases of the musculoskeletal system $(50 \%)$ and the cardiovascular system (42.5\%), which, in turn, significantly reduces the quality of life of former athletes. The studies on the structure of diseases of the musculoskeletal system revealed that $60 \%$ of diseases are related to osteochondrosis of the spine (Fedotova, 2010).

This type of trajectory is also related to a high mortality rate in elite sports, which is associated with the negative impact on the professional age of an athlete. Only Wikipedia (apart from other sources) contains information on 237 professional athletes who died during trainings or in the course of competitive activities. The analysis of the athletes' biographies ( $n=237$ ) allowed identifying the most dangerous sports, fraught with death: rally drivers ( $n=116,49 \%)$, alpinists $(n=46,195)$, football players $(n=37,16 \%)$, cycling athletes $(n=16,7 \%)$, ring fighter $(n=15$, $6 \%)$, ice hockey players $(n=6,3 \%)$.

The most frequent injuries incompatible with life are a blow to the head, a fracture of the spine. In the first place in the hierarchy of the causes of death among athletes is a heart attack due to the extreme physical overload of this professional group. Frequently enough, extreme loads are combined with the use of prohibited drugs consumed by athletes in order to achieve the higher results. The article "The Ninth Death in Two Years and the Fifth in the Last Two Months. Was it an Accident or Not? " (Lisin, 2018) published in 2018 states that none of the athletes introduced in the narrative had chronic health problems. In addition, all high-performance athletes undergo regular health check-ups, which include stress testing. As a result of the examination, the following fact was revealed: death in elite sports can potentially be considered as a possible consequence of the use of prohibited substances.

The identified trajectories of the impact of injuries on the course of a professional career allowed formulating the trajectories of professional ageing in the field of elite sports (see Fig. 2). 


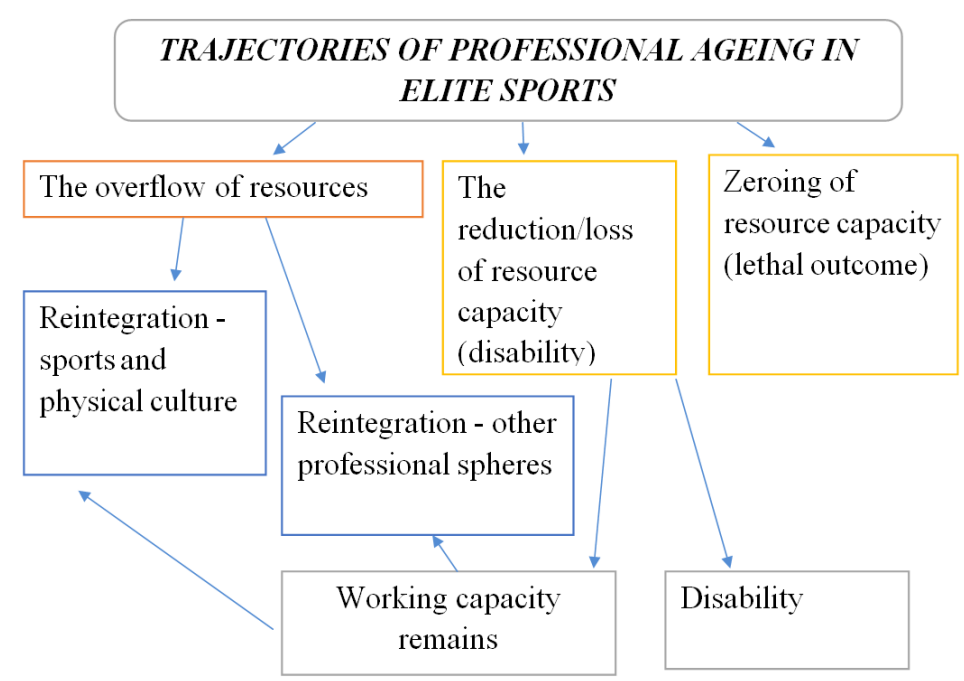

Figure 2. Trajectories of Professional Ageing in the Field of Elite Sports (authors of the study)

Within this study, the proposed positive trajectory for professional ageing all professional athletes should strive for is the athlete's "resource flow trajectory" as a result of which the former athlete can integrate into the labour market associated with the Physical Culture and Sports field (coach, sports judge, etc.) or into any other field of activity. However, without support from the state, the process of resource overflow, especially into other areas of labour activity, namely, integration into a professional field that is not related to sports, can be challenging. Therefore, the state should provide an opportunity to obtain the required level of education (quotas for places in the education system), undergo retraining courses, advanced training, taking into account the health status of former athletes. One of such measures may be implemented within the Dual Career framework which, in its turn, should be set as the priority within the state priority strategy.

This also applies to the European level. The European Union aims at support provision to student-athletes during and upon the completion of their professional careers proposing various initiatives and policy strategies. One of them is Dual Career program providing the opportunity to combine studies and sports (European Commission, 2007; 2012). This interest in educating student-athletes in the EU is linked to the fundamental right to education provided that these athletes give up their personal lives in favour of their friends, the state and the society (Schweiger, 2014).

It should be stated that in accordance with the Federal Law of the Russian Federation of August 22, 1996 No. 125-FZ “On Higher and 
Postgraduate Professional Education" champions and prize-winners of the Olympic Games, Paralympic Games and Deaflympics are admitted to state and municipal higher educational institutions for training in undergraduate programs and specialist training programs in areas (specialties) in the field of physical culture and sports without entrance examinations (Council of the Federation ..., 2011).

It should be highlighted that the social community of professional athletes includes not only champions and prize-winners of the above-mentioned sports competitions. To shed light upon this problem, the attention to the issue of the social environment of outstanding athletes should be turned. To exemplify, for instance, within combat sports - boxing, judo, sambo, aikido, etc. - the whole team of professionals (coaching staff, medical specialists, psychologists, etc.) is involved in the preparation of an athlete for the Olympic Games. A special role is assigned to athletes participating in training activities, namely, in sparring with a leader having the highest qualifying categories; they have to face no less risks (injuries) than the future Olympic champions. It is apparent that athletes who train an outstanding athlete for world competitions lose resources (for instance, health) even faster than the participants of the Olympic Games themselves, and their resource potential is much lower, because this category is not legally protected in some countries, for instance, in the Russian Federation (Federal Law No. 125-FZ "On Higher and Postgraduate Professional Education" Federal Law No. 253-F3 "On Pension Provisions for Persons Who Did Military Service ..."). Therefore, it is very crucial to revise the criteria for integrating athletes into the education system, into the sphere of labour relations, which will contribute to a painless overflow of the resources of this category of the population and, in general, increase the prestige of sports in the society.

The negative trajectories of professional ageing are, firstly, a decrease/ loss of resource capacity as a result of an athlete's disability; secondly, the zeroing of resource capacity as a result of the death of an athlete in the course of sports and training activities. A decrease in resource capacity implies that a representative of the Physical Culture and Sports field has a $2^{\text {nd }}$ or $3^{\text {rd }}$ group of disabilities, as a result of which a person retains the opportunity to integrate into the labour market, in contrast to the disabled of the 1st group, who, in the majority of cases, are not even capable of self-service. This substantiates the necessity to develop an institute of social support for athletes in difficult life situations, for instance, due to the presence of occupational diseases, disabilities, which complicate the process of their integration not only into the labour market, but also into the society as at large.

Already in 2007, the European Commission stated in its White Paper on Sport that it was crucial to provide young athletes with a "dual career" 
support at an early stage to ensure the reintegration of professional athletes into the labour market upon the completion of their sporting careers. (European Commission, 2007).

An athlete having a higher education is a valuable human resource and is competitive in the labour market.

Based on the international research, 30\% of young people between the ages of 10 and 18 who play sports quit every year due to thinking that it is too time-consuming.

In many countries (Latvia, Romania), where the development of a Dual Career is at an early stage, sports are not promoted as a career choice that can be successful not only during the active period, but also in advancement of the entire personal career. Therefore, the conclusion can be drawn that athletes frequently face psychological pressure - "now or never." You get all-or-nothing, and someone may no longer have that opportunity as an athlete's career is short-lived.

Dual Career allows looking at sports from a different perspective. It helps relieving psychological pressure and, at the same time, it is the support provision practice aimed at helping athletes achieve better results in sports.

In addition, a positive image of educated athletes will benefit society and sport by making sports and healthy lifestyle more attractive to others. Athletes would act as positive role models for youth and promote the society towards excellence.

\section{Conclusions}

The accumulated resources in the course of building and implementing a professional sports career have a positive impact on the duration of the professional career of the representatives of elite sports, which allows them to painlessly adjust to the new life upon the completion of the sports career (resource overflow trajectory). However, a professional career in this field can unexpectedly come to its end as a result of an injury, which may lead to the loss of resources and social insecurity. In the case of professional athletes, the orientation of the personality towards sports that has developed over the years makes it challenging for the re-socialization of former athletes. The authors of the research find such trajectories of professional aging as reduction/ loss of resource capacity (disability) with preservation and incapacitation, as well as zeroing resources (lethal outcome) of high-performance athletes of particular concern to be addressed at the state level. Lethal outcome in the course of sports and training activities, as the study showed, is a common social phenomenon especially in such sports as auto-racing, cycling, mountaineering, hockey, soccer, wrestling, which requires increased attention aimed at the development and implementation 
of the preventive measures to avoid accidents, such as sudden death (e. g., due to overexertion).

Therefore, taking into account the possible trajectories of professional ageing in the field of elite sports, such as decrease/loss, zeroing of resources, it is of urgent necessity to introduce changes, for instance, in the social policy of the country, strengthening the institution of social protection of professional athletes.

\section{References}

Bakunyeva, D. S. (2018a). Smisloziznennije orientacii v cisteme faktorov profesionalnoi uspesnosti sportsmenov - predstavitelei sporta vissih dostizenii. (Бакуняева, Д. С. Смысложизненные ориентации в системе факторов профессиональной успешности спортсменов - представителей спорта высших достижений) [Life-meaning orientations in the system of factors of professional success of athletes - representatives of elite sports] дис. канд. психол. наук: 19.00.03 / Бакуняева Дарья Сергеевна. М., 215 с.

Bakunyeva, D. S. (2018b). Sportivnaja travma kak istocnik cmisla vissih dostizenii in sportivnoi professii. (Бакуняева, Д. С. Спортивная травма как источник смысла высших достижений и спортивной профессии) [Sports injury as a source of the meaning of higher achievements and a sports profession] // Ресурсы конкурентоспособности спортсменов: теория и практика реализации, Издательство: Кубанский государственный университет физической культуры, спорта и туризма (Краснодар), рр. 23-25. (23)

Butova, E. S., Demyanova, L. M. (2018). Problemi socialnoi adaptacii sportsmenov posle zaversenie karjeri. (Бутова, Е. С., Демьянова, Л. М. Проблемы социальной адаптации спортсменов после завершения карьеры) [Problems of social adaptation of athletes after the end of their careers]// Наука без границ. Социологические науки. №5 (22). 2018. pp. 122-124.

European Commission. (2007). Commission staff document: Action plan "Pierre de Coubertin" accompanying document to the White Paper on Sport, Directorate-General Education and Culture. Brussels: EC.

European Commission. (2012). EU Guidelines on Dual Carrers of Athletes, Recommended policy actions in support of dual careers in high-performance sport. DOI: 10.2766/52683 Federation Council of the Federal Assembly of the Russian Federation (2011). Problemi socialnoi adaptacii sportsmenov: zakonodatelnii aspekt. (Сове́т Федера́ции Федерального Собрания Российской Федерации. Проблемы социальной адаптации спортсменов: законодательный аспект) [Problems of social adaptation of athletes: legislative aspect]. Available at: http://council.gov.ru/activity/ activities/roundtables/29529/

Fedotova, I. V. (2010). Mediko-socialnaja adoptacia sportsmenov visokoi kvalifikacii v postsportivnom periuge. (Федотова, И. В. Медико-социальная адаптация спортсменов высокой квалификации в постспортивном периоде) [Medical and social adaptation of highly qualified athletes in the post-sports period] / автореферат на соискание ученой степени кандидата медицинских наук. 14.02.05. Социология медицины. Волгоградский медицинских государственный университет Федерального агентства по здравоохранению и социальному развитию. Волгоград. 2010, р. 27.

Fedulova, D. V., Yamaletdinva, G. A. (2017). Psihologo-pedagogiceskie vozdeistvije na farmirovanie agaptacii sportsmenov posle serjoznoi sportivnoi travmi. (Федулова, Д. В., Ямалетдинова, Г. А. Психолого-педагогическое воздействие на формирование адаптации спортсменов после серьезной спортивной травмы) [Psychological and 
pedagogical influence on the formation of adaptation of athletes after a serious sports injury] // Педагогико-психологические и медико-биологические проблемы физической культуры и спорта. pp. 127-138.

Fedunina, N. J., Grushko, A. I., Kovaleva, A. V., Bannikov, G. S. (2018). Slucai konsultirovanija po povodu sportivnoi travmi na osnove metoda Pjera Zane. (Федунина, Н. Ю., Грушко, А. И., Ковалева, А. В., Банников, Г. С. Случай консультирования по поводу спортивной травмы на основе метода Пьера Жане) [A case of sports injury counseling based on the Pierre Janet method] // Вестник Московского университета. Серия 14. Психология. pp. 56-73.

Gorskaya, G. B., Sovmiz, Z. R. (2018). Psihologiceskie resursi preodolenija dolgovermennih psihiceskih nagruzok na raznih etapah profesionalnoi karjeri sportsmenob komandnih vidov sporta. (Горская, Г. Б., Совмиз, 3. Р. Психологические ресурсы преодоления долговременных психических нагрузок на разных этапах профессиональной карьеры спортсменов командных видов спорта) [Psychological resources for overcoming long-term mental stress at different stages of the professional career of athletes in team sports] // Физическая культура, спорт - наука и практика. №3. pp. 88-92.

Lisin, S. (2018). Devjat smert za dva goda i pjataja - za poslednije dva mesjaca Slucainost ili net? (Лисин, С. Девятая смерть за два года и пятая - за последние два месяца Случайность или нет?) [The ninth death in two years and the fifth in the last two months Accident or not] Available at: https://matchtv.ru/doping/matchtvnews_NI841895_ Devataja_smert_za_dva_goda_i_pataja_za_poslednije_dva_mesaca_Sluchajnost_ili_net

Mc Namara, M. (2012). Vrad li u kitaicov jest cudesnaja tabletka. (Макнамара М. Вряд ли у китайцев есть чудесная таблетка) [It is unlikely that the Chinese have a wonderful pill]. Газета. ru. Available at: https://www.gazeta.ru/science/2012/06/18_a_4630137. shtml

Pristrom, M. S., Pristrom, S. L., Simankov, S. S. (2015). Starenie fiziologiceskoje i prezdevremennoje. Sovremennii vzgljad na problēmu. (Пристром, М. С., Прситром, С. Л., Симонков, С. С. Старение физиологическое и преждевременное. Современный взгляд на проблему) [Aging is physiological and premature. Modern view of the problem ]// Медицинские новости. Науки о здоровье, 2015, №2., Available at: https://cyberleninka.ru/article/n/ starenie-fiziologicheskoe-i-prezhdevremennoe-sovremennyy-vzglyad-na-problemu

Sporta traumatisms. (2012). (Sports Injury) Medicine.lv, available at: https://medicine. lv/raksti/sporta_traumatisms_pme

Schweiger, G. (2014). What does a professional athlete deserve? Prolegomena, 13(1), $5-20$.

Youth Sports Safety Statistic. (2014). Athletic Injuries and Health Care the United States. Available at: https://www.youthsportssafetyalliance.org/sites/default/files/ Statistics.pdf

Zolotov, M. I. (2003). Formirovanie resursnova obespecenie massovova sporta. (Золотов, М. И. Формирования ресурсного обеспечения массового спорта) [Formation of resource support for mass sports] / автореферат на соискание научной степени доктора экономических. Специальность 08.00.05. Экономика и управление народным хозяйством (экономика, организация и управление предприятиями, отраслями и комплексами: сфера услуг). Москва. Московский государственный университет сервиса. р. 52.

The research was conducted with the support of the RFBR. Project 18-411-520002 "Health Preservation in the Practices of the Modern Nizhny Novgorod Family". 